\title{
Pertumbuhan dan Produksi Tanaman Kacang Hijau (Vigna radiata L.) pada Berbagai Konsentrasi Osmolit Sorbitol dan Intensitas Cekaman Kekeringan
}

\author{
Growth and Production of Mung Beans (Vigna radiata L.) at Various Sorbitol Osmolite Concentrations \\ and Drought Stress Intensities \\ Suhartono ${ }^{1 *}$, Gita Pawana ${ }^{1}$, dan Sulistri ${ }^{1}$ \\ ${ }^{1}$ Program Studi Agroteknologi; Fakultas Pertanian; Universitas Trunojoyo Madura \\ Jalan Raya Telang PO BOX 02 Kamal, Bangkalan, Madura \\ *Email korespondensi: hartono_unijoyo@yahoo.co.id
}

Diterima: 28 Agustus 2020 / Disetujui: 30 September 2020

\begin{abstract}
Mung bean is one type of food plants that has an important role as a source of nutrients, i.e as a source of carbohydrates, proteins and minerals, and has a better marketing prospect that can increase farmers' income. The ability of plants to grow normally under drought conditions is referred to adaptability. One cultivation technology that can be applied to overcome these conditions is through the setting of open and close of plant stomata by spraying osmolite on plant leaves. The purpose of this research is to know the response of growth and production of mung bean plants due to the supply of osmolite sorbitol at different intensity of drought stress. This study is expected to increase the resilience of mung bean plants cultivated in lack water conditions. The experiment is conducted in plastic house using factorial RAL consisting of 2 factors, namely sorbitol concentration with 4 levels $(0,10,20$ and $30 \mathrm{ml} / \mathrm{l})$ and intensity of drought stress with 4 levels (unstressed, drought stress from vegetative stadia, flowering, and filling pods to harvest). The results show that sorbitol osmolite 10, 20, and $30 \mathrm{ml} / \mathrm{l}$ have not been able to increase the production of green beans under drought conditions such as cultivated plants under normal conditions (not drought), but to obtain efficient application of sorbitol osmolite using concentration of $30 \mathrm{ml} / \mathrm{l}$ carried out in plants with the longest drought stress, i.e ve getative stadia.
\end{abstract}

Keyword: Mung Beans, Drought Stress, Osmolite, and Sorbitol

\section{ABSTRAK}

Kemampuan tanaman untuk tumbuh normal pada kondisi tercekam kekeringan disebut sebagai daya adaptasi. Salah satu teknologi budidaya yang dapat diterapkan untuk meningkatkan daya adaptasinya pada kondisi tercekam kekeringan adalah dengan penyemprotan osmolit pada daun tanaman. Tujuan dari penelitian ini adalah untuk mengetahui respon pertumbuhan dan produksi tanaman kacang hijau akibat pemberian osmolit sorbitol pada intensitas cekaman kekeringan yang berbeda. Penelitian dilakukan di dalam rumah kaca dengan menggunakan RAL faktorial yang terdiri dari 2 faktor, yaitu konsentrasi sorbitol dengan 4 taraf $(0,10,20$, dan $30 \mathrm{ml} / \mathrm{l})$ dan intensitas cekaman kekeringan dengan 4 taraf (tidak tercekam, tercekam kekeringan mulai stadia vegetatif, pembungaan, dan pengisian polong sampai panen). Hasil penelitian menunjukkan pemberian osmolit sorbitol 10, 20, dan $30 \mathrm{ml} / \mathrm{l}$ belum mampu meningkatkan produksi kacang hijau pada kondisi tercekam kekeringan seperti tanaman yang dibudidayakan pada kondisi normal (tidak tercekam kekeringan), namun untuk mendapatkan hasil aplikasi osmolit sorbitol yang efesien yaitu dengan menggunakan konsentrasi $30 \mathrm{mlll}$ yang dilakukan pada tanaman yang mendapat cekaman kekeringan paling lama yaitu mulai stadia vegetatif.

Kata kunci: Kacang Hijau, Cekaman Kekeringan, Osmolit, dan Sorbitol

\section{PENDAHULUAN}

Kacang hijau adalah salah satu jenis tanaman pangan yang memiliki peranan penting sebagai sumber nutrisi. Menurut Rukmana (1997) tanaman ini bersifat multiguna. Kandungan karbohidrat dalam 100 g kacang hijau sejumlah 62,9 g yang nilainya lebih tinggi dibandingkan kandungan karbohidrat pada kedelai dan kacang tanah. Thippeswamy et al., (2015) dan Kaur et al., (2017) menyatakan selain sebagai sumber karbohidrat, kacang hijau merupakan sumber protein dan mineral. Hasil penelitian Hussain (2011) menjelaskan bahwa kacang hijau memiliki nilai gizi tinggi yang bijinya mengandung protein 24,2\%, 1,3\% lemak dan 60,4\% karbohidrat. Selain itu kacang hijau juga berperan penting 
dalam meningkatkan kesuburan tanah (Das et al., 2015), karena tanaman ini termasuk golongan legume yang akarnya bersimbiosis dengan bakteri Rhizobium sebagai pengikat Nitrogen bebas menjadi Nitrogen tersedia (Yasmeen et al., 2012). Tanaman ini juga memiliki umur panen yang singkat dan memiliki toleransi terhadap kondisi kekeringan (Ullah et al., 2014 dan Liu et al., 2016). Kacang hijau di Indonesia menempati urutan ketiga terpenting sebagai tanaman pangan kacang-kacangan setelah kedelai dan kacang tanah (Trustinah et al., 2014). Pusat data dan sistem informasi pertanian menjelaskan rata-rata penggunaan kacang hijau selama tahun 2011-2015 adalah 307,69 ton, sedangkan produksi kacang hijau yang diperoleh menunjukkan nilai 268,25 ton dan impor kacang hijau mencapai 71,23 ton (Komalasari, 2015). Arsyadmunir (2016) melaporkan bahwa salah satu penyebab rendahnya produksi kacang hijau adalah kekurangan air, berdasarkan data yang dilaporkan oleh BNPB (2017) kekeringan di Indonesia melanda 56,334 ha lahan pertanian yang menyebabkan 18,516 ha lahan pertanian gagal panen (Tribun Timur, 2017).

Masalah kekurangan air pada tanam-an budidaya, memiliki resiko penurunan laju pertumbuhan dan pengurangan produktivitas secara keseluruhan, dikarenakan tanaman berada dalam kondisi tercekam. Shinozaki dan Kazuko (2007) melaporkan kondisi tersebut berpengaruh pada aktivitas fisiologis dan biokimia tanaman yang dapat menyebabkan penutupan stomata, penghambatan pertumbuhan sel dan fotosintesis, serta aktivasi respirasi pada tingkat seluler maupun molekuler. Upaya untuk meningkatkan toleransi terhadap kekeringan lebih diarahkan pada pengaturan membuka dan menutupnya stomata (Ariffin, 2002).

Upaya yang dapat dilakukan berdasarkan uraian tersebut dapat dilakukan dengan dilakukannya rekayasa melalui teknologi budidaya yang dapat diterapakan untuk pengaturan membuka menutupnya stomata adalah dengan penyemprotan osmolit pada daun tanaman. Aminah et al., (2013) memaparkan bahwa agar stomata tidak selalu menutup, dapat ditempuh dengan memperkecil peranan ABA di dalam daun dengan menggunakan senyawa osmolit sorbitol, pada penyemprotan osmolit sorbitol sebanyak 20

$\mathrm{ml} / \mathrm{L}$ pada daun dapat meningkatkan ketahanan tanaman kedelai terhadap kekeringan. Ariffin (2002) menjelaskan bahwa tingkat keberhasilan penyemprotan osmolit sorbitol pada tanaman kacang hijau yang tercekam kekeringan pada berbagai stadia menunjukkan tidak berbeda nyata dengan kacang hijau yang diberi pengairan normal. Berdasarkan uraian tersebut perlu adanya pengembangan penelitian mengenai pengaruh osmolit sorbitol pada intensitas cekaman kekeringan yang berbeda dari penelitian sebelumnya sebagai rekomendasi untuk manambah pengetahuan petani.

\section{METODE}

Penelitian dilaksanakan pada bulan Maret hingga Juni 2018 di kebun percobaan Agroteknologi Universitas Trunojoyo
Madura, dengan ketinggian tempat $\pm 5 \mathrm{~m}$ dpl.

Alat yang digunakan adalah pot plastik dengan ukuran diameter permukaan $30 \mathrm{~cm}$ dan tinggi $19 \mathrm{~cm}$, gembor, papan nama, plastik, cangkul, cetok, sprayer, ring tanah, oven, timbangan, gunting, kamera, mikroskop, dan penanda. Sedangkan bahan yang digunakan adalah benih kacang hijau varietas Vima-1, tanah mediteran (alfisol), air AC, kutek bening, pestisida regent, pupuk kandang, urea, SP-36, dan $\mathrm{KCl}$.

Penelitian disusun dengan Rancangan Acak Lengkap (RAL) faktorial yang tediri dari dua faktor yaitu, faktor pertama konsentrasi osmolit sorbitol (S) dengan empat taraf: $\mathrm{S} 0=0$ $\mathrm{ml} / 1, \mathrm{~S} 1=10 \mathrm{ml} / \mathrm{l}$. S2 $=20 \mathrm{ml} / \mathrm{l}$. dan S3=30 ml/l, faktor kedua intensitas cekaman kekeringan (W) dengan empat taraf: $\mathrm{W} 0=$ tanpa cekaman kekeringan dari awal tanam sampai panen, W1 = tercekam kekeringan mulai stadia vegetatif pada umur 14 HST (Hari Setelah Tanam) sampai panen, W2 = tercekam kekeringan mulai stadia pembungaan, pada umur \pm 25 HST saat muncul bunga $80 \%$ sampai panen), dan $\mathrm{W} 3=$ tercekam kekeringan mulai stadia pengisian polong, pada umur \pm 45 HST sampai panen.

Tanah yang digunakan sebanyak $7 \mathrm{~kg}$ dengan menambahkan pupuk kandang $150 \mathrm{~g}$ sebagai pupuk dasar. Benih kacang hijau ditanam pada pot plastik dengan kedalaman tanam $2 \mathrm{~cm}$. Volume air yang ditambahkan ialah sesuai dengan kehilangan jumlah air (gravimetrik), pengairan pada kontrol dilakukan setiap hari ( $\pm 200 \mathrm{ml})$, sedangkan pada tanaman yang tercekam kekeringan, dilakukan ketika kadar air tanah mencapai $12,59 \%$, yaitu dengan volume $\pm 900 \mathrm{ml}$. Pengaplikasian osmolit sorbitol dilakukan setiap hari pada kondisi tanaman mulai tercekam, yaitu ketika kadar air tanah mencapai $22,17 \%$ pada pukul 09.00 pagi. penyemprotan diarahkan pada permukaan daun bagian bawah. Pemupukan susulan dilakukan pada saat tanaman berumur 30 HST dengan dosis yang digunakan yaitu pupuk Urea $0,1 \mathrm{~g} / \mathrm{tanaman}$, pupuk SP-36 0,3 g/tanaman dan pupuk $\mathrm{KCl}$ 0,1 g/tanaman (Arsyadmunir, 2016). Pemeliharaan meliputi pengendalian hama dan penyakit, serta gulma. Pembuatan preparat stomata dilakukan dengan mengolesi kutek bening dibawah permukaan daun yang dilanjutkan dengan menempelkan solatip di atas kutek yang telah kering kemudian melepaskannya dan menempelkan solatip pada preparat, selanjutnya diamati dengan mikroskop dengan perbesaran 40x. Pengambilan stomata dilakukan pada pukul 10.00 pagi. Pemanenan mulai dilakukan ketika tanaman telah berumur 73 HST atau pada saat polong telah masak secara fisologis, yaitu ketika polong berwarna kehitaman.

Parameter yang diamati meliputi tinggi tanaman, panjang akar, jumlah polong total, jumlah polong utuh, jumlah biji per tanaman, berat biji per tanaman, berat 100 butir biji, bera kering total, dan indeks panen. Hasil pengamatan dianalisis dengan menggunakan Analysis of Variance (ANOVA) dengan taraf 5\%. Apabila ada pengaruh nyata maka akan diuji lanjut dengan menggunakan uji Beda Jarak nyata Duncan (BJND) $5 \%$. 


\section{HASIL DAN PEMBAHASAN}

\section{Tinggi Tanaman}

Pemberian konsentrasi osmolit sorbitol pada intensitas cekaman kekeringan pada stadia yang berbeda menunjukkan pengaruh nyata pada parameter pengamatan tinggi tanaman saat 3 MST, sedangkan untuk 4-6 MST pemberian perlakuan tidak berpengaruh terhadap parameter tinggi tanaman.

Tabel 4.1 menunjukkan tinggi tanaman kacang hijau pada 3 MST S0W1 menunjukkan rata-rata tinggi tanaman yang paling rendah yaitu $9,55 \mathrm{~cm}$, nilai ini berbeda tidak nyata dengan S2W0, S1W0, dan S3W3. Rata-rata tinggi tanaman tertinggi terdapat pada perlakuan SOW0, yaitu $14,17 \mathrm{~cm}$, nilai ini menunjukkan tidak berbeda nyata dengan S2W1dan perlakuan pada stadia yang lain.

\section{Panjang Akar}

Tabel 4.2 menunjukkan tidak adanya pengaruh akibat interaksi osmolit sorbitol dan intensitas cekaman kekeringan pada parameter panjang akar, namun pemberian perlakuan osmolit sorbitol menunjukkan pengaruh nyata pada parameter tersebut. Tabel 4.2 menunjukkan tidak adanya pengaruh akibat interaksi osmolit sorbitol dan intensitas cekaman kekeringan pada parameter panjang akar, namun pemberian perlakuan osmolit sorbitol menunjukkan pengaruh nyata pada parameter tersebut.

Berdasarkan Tabel 4.2 panjang akar tertinggi yaitu terdapat pada perlakuan tanpa pemberian osmolit sorbitol (S0) yaitu $43,71 \mathrm{~cm}$. Nilai ini tidak berbeda nyata dengan $\mathrm{S} 2$ dan $\mathrm{S} 3$, namun S0 cenderung menunjukkan nilai yang lebih tinggi dibandingan dengan S2 dan S3. Panjang akar paling rendah terdapat pada S1, yaitu 29,15 yang menunjukkan berbeda nyata lebih rendah dibandingkan perlakuan yang lainnya

Jumlah Polong Utuh, Polong Total, dan Berat Kering Polong per Tanaman Berdasarkan hasil analisis menunjukkan adanya pengaruh nyata akibat interaksi antara beberapa konsentrasi osmolit sorbitol dan intensitas cekaman kekeringan yang berbeda terhadap rata-rata jumlah polong utuh, jumlah polong total. dan berat kering polong per tanaman (Tabel 4.3)

Tabel 4. 1. Rata-Rata Tinggi Tanaman Kacang Hijau Akibat Interaksi Beberapa Konsentrasi Osmolit Sorbitol dan Intensitas Cekaman Kekeringan yang Berbeda

\begin{tabular}{|c|c|c|c|c|c|}
\hline \multirow[t]{2}{*}{ Perlakuan } & \multicolumn{5}{|c|}{ Tinggi tanaman $(\mathrm{cm})$ pada umur (MST) } \\
\hline & \multicolumn{2}{|c|}{3} & 4 & 5 & 6 \\
\hline S0W0 & 14,17 & $\mathrm{c}$ & 16,55 & 20,62 & 23,88 \\
\hline S0W1 & 9,55 & $\mathrm{a}$ & 12,13 & 13,97 & 17,20 \\
\hline S0W2 & 12,07 & $\mathrm{bc}$ & 14,13 & 18,15 & 20,10 \\
\hline S0W3 & 12,25 & $\mathrm{bc}$ & 14,28 & 20,13 & 19,97 \\
\hline S1W0 & 11,82 & $a b c$ & 13,58 & 17,62 & 19,13 \\
\hline S1W1 & 12,27 & bc & 12,78 & 14,00 & 17,60 \\
\hline S1W2 & 13,10 & $\mathrm{bc}$ & 14,77 & 19,52 & 20,23 \\
\hline S1W3 & 13,42 & $\mathrm{bc}$ & 17,37 & 20,87 & 24,60 \\
\hline S2W0 & 11,20 & $a b$ & 12,32 & 15,03 & 19,25 \\
\hline S2W1 & 13,83 & $\mathrm{c}$ & 15,05 & 17,25 & 18,90 \\
\hline S2W2 & 12,57 & $\mathrm{bc}$ & 14,08 & 17,33 & 18,12 \\
\hline S2W3 & 12,97 & $\mathrm{bc}$ & 14,27 & 16,05 & 20,82 \\
\hline S3W0 & 13,13 & $\mathrm{bc}$ & 14,35 & 16,82 & 22,42 \\
\hline S3W1 & 13,23 & $\mathrm{bc}$ & 14,10 & 16,38 & 19,57 \\
\hline S3W2 & 12,58 & bc & 13,67 & 18,42 & 19,47 \\
\hline S3W3 & 11,97 & $a b c$ & 13,20 & 16,72 & 20,18 \\
\hline BJND 5\% & \multicolumn{2}{|c|}{$*$} & $\mathrm{~ns}$ & $\mathrm{~ns}$ & ns \\
\hline
\end{tabular}

Keterangan: Angka yang diikuti huruf yang sama menunjukkan tidak berbeda nyata, ${ }^{*}=$ berpengaruh nyata, $n s=$ non significant 
Tabel 4. 2. Rata-Rata Panjang Akar Akibat Pemberian Beberapa Konsentrasi Osmolit Sorbitol dan Intensitas Cekaman Kekeringan yang Berbeda

\begin{tabular}{ll}
\hline Perlakuam & Panjang Akar $(\mathrm{cm})$ \\
\hline Konsentrasi Sorbitol & \\
S0 & $43,71 \mathrm{~b}$ \\
S1 & $29,15 \mathrm{a}$ \\
S2 & $37,73 \mathrm{~b}$ \\
S3 & $37,83 \mathrm{~b}$ \\
\hline BJND 5\% & $*$ \\
\hline Intensitas Cekaman Kekeringan & \\
W0 & 38,19 \\
W1 & 35,77 \\
W3 & 38,63 \\
\hline BJND 5\% & 35,83 \\
\hline
\end{tabular}

Keterangan: Angka yang diikuti huruf yang sama menunjukkan tidak berbeda nyata, ${ }^{*}=$ berpengaruh nyata, $n s=$ non significant

Tabel 4. 3. Rata-Rata Jumlah Polong Utuh, Polong Total, Berat Kering Polong per Tanaman Akibat Interaksi Beberapa Konsentrasi Pemberian Osmolit Sorbitol dan Intensitas Cekaman Kekeringan yang Berbeda

\begin{tabular}{|c|c|c|c|c|c|c|}
\hline \multirow{2}{*}{$\begin{array}{l}\text { Perlakuan } \\
\text { S0W0 }\end{array}$} & \multicolumn{2}{|c|}{$\begin{array}{c}\text { Jumlah Polong Utuh / } \\
\text { Tanaman (buah) }\end{array}$} & \multicolumn{2}{|c|}{$\begin{array}{c}\text { Jumlah Polong } \\
\text { Total/Tanaman (buah) }\end{array}$} & \multicolumn{2}{|c|}{$\begin{array}{c}\text { Berat Kering } \\
\text { Polong/Tanaman }(\mathrm{g})\end{array}$} \\
\hline & 13,33 & f & 17,00 & $\mathrm{e}$ & 12,67 & $\mathrm{~g}$ \\
\hline S0W1 & 3,33 & $a b$ & 6,00 & $a b$ & 3,46 & $\mathrm{a}$ \\
\hline S0W2 & 3,33 & $a b$ & 8,00 & $a b c$ & 4,25 & $a b c$ \\
\hline S0W3 & 7,33 & de & 11,00 & $\mathrm{~cd}$ & 6,56 & cdef \\
\hline S1W0 & 6,33 & $\mathrm{~cd}$ & 7,33 & $a b c$ & 8,40 & ef \\
\hline S1W1 & 4,00 & $a b$ & 4,67 & $\mathrm{a}$ & 3,31 & $\mathrm{a}$ \\
\hline S1W2 & 4,33 & $a b$ & 9,00 & abcd & 3,37 & $\mathrm{a}$ \\
\hline S1W3 & 6,33 & $\mathrm{~cd}$ & 14,00 & de & 6,03 & bcde \\
\hline S2W0 & 7,33 & de & 8,67 & $a b c$ & 7,64 & def \\
\hline S2W1 & 2,67 & $\mathrm{a}$ & 8,67 & $a b c$ & 3,60 & $\mathrm{ab}$ \\
\hline S2W2 & 4,67 & $\mathrm{bc}$ & 11,00 & $\mathrm{~cd}$ & 5,34 & abcd \\
\hline S2W3 & 8,33 & $\mathrm{e}$ & 12,00 & cde & 6,96 & def \\
\hline S3W0 & 4,33 & $a b$ & 11,33 & $\mathrm{~cd}$ & 5,86 & bcde \\
\hline S3W1 & 6,33 & $\mathrm{~cd}$ & 11,33 & $\mathrm{~cd}$ & 6,72 & cdef \\
\hline S3W2 & 4,67 & $\mathrm{bc}$ & 9,67 & bcd & 5,39 & abcd \\
\hline S3W3 & 5,33 & $\mathrm{bc}$ & 10,33 & bed & 8,90 & f \\
\hline BJND 5\% & \multicolumn{2}{|c|}{ * } & \multicolumn{2}{|c|}{ * } & \multicolumn{2}{|c|}{$*$} \\
\hline
\end{tabular}

Keterangan: Angka yang diikuti huruf yang sama pada kolom yang sama menunjukkan tidak berbeda nyata, ${ }^{*}=$ berpengaruh nyata.

Berdasarkan Tabel 4.3 S0W0 menunjukkan hasil tertinggi pada parameter jumlah polong per tanaman, yaitu dengan nilai 13,33 buah per tanaman, namun S0 pada hasil kombinasi dengan $\mathrm{W} 1$ dan $\mathrm{W} 2$ menunjukkan hasil rata-rata jumlah polong yang lebih rendah, nilai tersebut menunjukkan tidak berbeda nyata dengan perlakuan S1 yang dikombinasikan dengan perlakuan intensitas cekaman kekeringan yang sama. S2W1 menunjukkan hasil terendah dari semua perlakuan yang diberikan, yaitu 2,67 rata-rata jumlah polong utuh, sedangkan S3W1, S3W2, dan S3W3 menunjukkan hasil yang tidak berbeda nyata.

Jumlah polong total S0W0 menunjukkan rata-rata jumlah polong total tertinggi dan berbeda nyata dengan perlakuan yang lain, yaitu sebanyak $17 \mathrm{~g}$ per tanaman, S0W1 menunjukkan tidak berbeda nyata dengan S1W1 dan S2W1, pemberian osmolit sorbitol dengan konsentrasi $30 \mathrm{ml} / \mathrm{l}$ (S3) mampu meningkatkan jumlah polong total sebanyak $88,83 \%$ pada kondisi tercekam kekeringan mulai stadia vegetatif (W1), sedangkan W2 dan W3 yang dikombinasikan dengan berbagai tingkat konsentrasi osmolit sorbitol menunjukkan tidak berbeda nyata pada masing-masing stadia tersebut, namun secara statistik pada S3W2 cenderung menunjukkan nilai tertinggi dan mampu meningkatkan jumlah polong total sebanyak 20,87\% dan pada S1W3 sebanyak 27,27\% jika 
dibandingkan dengan tanpa pemberian osmolit sorbitol pada masing-masing intensitas cekaman tersebut.

Tabel 4.3 juga menunjukkan rata-rata berat kering polong tertinggi yaitu terdapatsebesar $35,67 \%$ pada stadia perlakuan cekaman kekeringan mulai pengisian polong (W3). Jumlah Biji (buah), Berat Biji (g), dan Berat 100 Butir Biji (g) per Tanaman Hasil yang berpengaruh nyata ditunjukkan akibat adanya interaksi pemberian konsentrasi osmolit sorbitol dan intensitas cekaman kekeringan yang berbeda terhadap parameter jumlah biji dan berat total biji per tanaman. Berikut adalah Tabel 4.4 yang menunjukkan hasil dari analisis tersebut: pada SOW0 dengan nilai 12,67 g yang menunjukkan berbeda nyata lebih tinggi dibandingkan dengan perlakuan yang lainnya, Hasil rata-rata berat kering polong terendah terdapat pada W1, perlakuan tersebut menunjukkan tidak berbeda nyata dengan kombinasi perlakuan pemberian osmolit sorbitol, kecuali S3W1, kombinasi tersebut menghasilkan rata-rata berat kering polong tertinggi, yaitu 6,72 g dan mampu meningkatkan hasil sebesar 94,22\% pada kondisi tercekam kekeringan mulai stadia vegetatif (W1). Perlakuan cekaman kekeringan pada saat mulai stadia pembungaan menunjukkan hasil berat kering polong yang tidak berbeda nyata pada semua perlakuan yang diberikan. Hasil terendah didapatkan pada kombinasi dengan $\mathrm{S} 1$ yaitu 3,37 g. Pada perlakuan cekaman kekeringan mulai pengisian polong (W3) menunjukkan penambahan osmolit sorbitol cenderung menunjukkan hasil lebih baik dibandingkan tanpa penambahan osmolit sorbitol, namun antara dengan pemberian dan tanpa osmolit menunjukkan tidak berbeda nyata, pada kombinasi dengan S3 menunjukkan hasil rata- rata berat polong tertinggi dan mampu meningkatkan rata-rata berat polong kering.

Pada parameter pengamaatan jumlah biji dan berat biji per tanaman menunjukkan perlakuan tanpa pemberian osmolit dan perlakuan tanpa cekaman kekeringan (SOW0) menujukkan hasil tertinggi yaitu 137,33 dan 8,71 g, hasil ini menunjukkan berbeda nyata dengan W0 yang dikombinasikan dengan pemberian osmolit sorbitol pada berbagai tingkat konsentrasi, yang mana kombinasi tersebut berdasarkan analisis menurunkan rata- rata jumlah biji dan berat biji per tanaman.

Pada intensitas cekaman kekeringan mulai stadia vegetatif menujukkan pemberian osmolit sorbitol pada konsentrasi $10 \mathrm{ml} / \mathrm{l}$ berdasarkan analisis menurunkan jumlah biji dan berat biji per tanaman sebesar $174 \%$ dan $201 \%$ pada kondisi cekaman kekeringan yang diberikan, sedangkan untuk pemberian konsentrasi 20 dan $30 \mathrm{ml} / \mathrm{l}$ menunjukkan tidak berbeda nyata dengan perlakuan yang tidak diberikan osmolit sorbitol pada kondisi tersebut. Konsentrasi osmolit sorbitol juga tidak menunjukkan perbedaan yang nyata pada perlakuan intensitas cekaman kekeringan mulai stadia pembungaan dan pengisian polong, sebagaimana tersaji dalam Tabel 4.4 tersebut. Pada konsentrasi sorbitol tertinggi (S3) menunjukkan tidak berbeda nyata dengan hasil kombinasi W1, W2, dan W3. Hal ini menunjukkan pada konsentrasi $30 \mathrm{ml} / \mathrm{l}$ osmolit sorbitol mampu meningkatkan adaptasi pada tanaman yang tercekam paling lama, yaitu mulai stada vegetatif.

Tabel 4. 4. Rata-Rata Jumlah Biji dan Berat Biji per Tanaman Akibat Interaksi Beberapa Konsentrasi Pemberian Sorbitol dan Intensitas Cekaman Kekeringan yang Berbeda

\begin{tabular}{|c|c|c|}
\hline Perlakuan & Jumlah Biji / Tanaman (buah) & Berat Biji/ Tanaman (g) \\
\hline S0W0 & $137,33 \quad \mathrm{~d}$ & $8,71 \mathrm{~d}$ \\
\hline S0W1 & 53,00 bc & 3,18 abc \\
\hline SoW2 & $43,00 \quad a b$ & $2,93 \mathrm{abc}$ \\
\hline SoW3 & 53,33 bc & 3,93 bc \\
\hline S1W0 & $78,00 \quad c$ & $4,73 \mathrm{c}$ \\
\hline S1W1 & 19,33 & 1,17 a \\
\hline S1W2 & $32,00 \quad a b$ & $2,08 \mathrm{ab}$ \\
\hline S1W3 & 48,00 & $3,42 \mathrm{bc}$ \\
\hline S2W0 & 61,00 & 3,87 bc \\
\hline S2W1 & 46,33 & $2,78 \mathrm{abc}$ \\
\hline $\mathrm{S} 2 \mathrm{~W} 2$ & 40,67 & $2,61 \mathrm{abc}$ \\
\hline S2W3 & $44,00 \quad a b$ & 3,21 abc \\
\hline S3W0 & 59,33 bc & 4,33 bc \\
\hline S3W1 & 80,00 & $4,80 \mathrm{c}$ \\
\hline S3W2 & $42,67 \quad a b$ & 4,09 bc \\
\hline S3W3 & $40,00 \quad a b$ & $2.80 \mathrm{abc}$ \\
\hline BNJD 5\% & $*$ & $*$ \\
\hline
\end{tabular}

Keterangan: Angka yang diikuti huruf yang sama pada kolom yang sama menunjukkan tidak berbeda nyata, $*$ berpengaruh nyata. 
Tabel 4. 5. Rata-Rata Berat 100 Butir Biji per Tanaman Akibat Pemberian Beberapa Konsentrasi Pemberian Sorbitol dan Intensitas Cekaman Kekeringan yang Berbeda

\begin{tabular}{ll}
\hline Perlakuam & Berat 100 Butir (g) \\
Konsentrasi Sorbitol & 6,74 \\
S0 & 7,04 \\
S1 & 6,62 \\
S2 & 6,98 \\
S3 & $n s$ \\
\hline BJND 5\% & $7,08 \mathrm{~b}$ \\
W0 & $6,24 \mathrm{a}$ \\
W1 & $7,00 \mathrm{~b}$ \\
W2 & $7,07 \mathrm{~b}$ \\
\hline W3 & $*$ \\
\hline
\end{tabular}

Keterangan: Angka yang diikuti huruf yang sama menunjukkan tidak berbeda nyata, ${ }^{*}=$ berpengaruh nyata, $n s=$ non significant

Tabel 4. 6. Rata-Rata Berat Kering dan Rasio Tajuk Akar Tanaman Akibat Pemberian Beberapa Konsentrasi Pemberian Sorbiol dan Intensitas Cekaman Kekeringan yang Berbeda

\begin{tabular}{lcr}
\hline Perlakuam & Berat Kering Total $(\mathrm{g})$ & Rasio Tajuk Akar \\
\hline Konsentrasi Sorbitol & & \\
S0 & $6,25 \mathrm{~b}$ & 9,54 \\
S1 & $4,72 \mathrm{a}$ & 8,85 \\
S2 & $4,51 \mathrm{a}$ & 10,40 \\
S3 & $4,22 \mathrm{a}$ & \multicolumn{1}{c}{$n$} \\
\hline BJND 5\% & $*$ & $13,64 \mathrm{~b}$ \\
\hline Intensitas Cekaman Kekeringan & & $7,27 \mathrm{a}$ \\
W0 & $7,03 \mathrm{c}$ & $6,98 \mathrm{a}$ \\
W1 & $4,20 \mathrm{ab}$ & $9,66 \mathrm{a}$ \\
W2 & $3,59 \mathrm{a}$ & $*$ \\
W3 & $4,87 \mathrm{~b}$ & $*$ \\
\hline BJND 5\% & &
\end{tabular}

Tabel 4. 7. Rata-Rata Indeks Panen Akibat Pemberian Beberapa Konsentrasi Osmolit Sorbitol dan Intensitas Cekaman Kekeringan yang Berbeda

\begin{tabular}{lc}
\hline Perlakuam & Indeks Panen \\
\hline Konsentrasi Sorbitol & \\
S0 & $0,74 \mathrm{a}$ \\
S1 & $0,58 \mathrm{a}$ \\
S2 & $0,78 \mathrm{ab}$ \\
S3 & $1,05 \mathrm{~b}$ \\
BJND 5\% & $*$ \\
\hline Intensitas Cekaman Kekeringan & 0,77 \\
W0 & 0,77 \\
W1 & 0,88 \\
W3 & 0,72 \\
\hline BJND 5\% & $n s$ \\
\hline
\end{tabular}

Keterangan: Angka yang diikuti huruf yang sama menunjukkan tidak berbeda nyata, ${ }^{*}=$ berpengaruh nyata, $n s=$ non significant 
Pada parameter pengamatan berat 100 butir biji menunjukkan tidak adanya pengaruh akibat interaksi pemberian osmolit sorbitol dan intensitas cekaman kekeringan yang berbeda, namun pada perlakuan intensitas cekaman kekeringan menunjukkan hasil berpengaruh nyata, sedangkan pada perlakuan pemberian konsentrasi osmolit sorbitol yang berbeda menunjukkan tidak adanya pengaruh, pernyataan tersebut diuraikan pada Tabel 4.5 berikut:

Pemberian perlakuan intensitas cekaman kekeringan mulai stadia vegetatif (W1) menunjukkan berat 100 butir biji terendah, yaitu $2,81 \mathrm{~g}$. Hal ini berarti pada kondisi tersebut dapat menurunkan berat 100 butir biji sebesar 38\%. Sedangkan pada intensitas cekaman kekeringan mulai stadia pembungaan dan pengisian polong menunjukkan hasil yang tidak berbeda nyata dengan perlakuan tanpa cekaman kekeringan.

Berat Kering dan Rasio Tajuk Akar Tanaman (g) Berat kering dan rasio tajuk akar tidak menunjukkan adanya pengaruh akibat interaksi pemberian konsentrasi osmolit sorbitol dan intensitas cekaman kekeringan, namun dari masing-masing faktor perlakuan memberikan pengaruh nyata terhadap parameter tersebut, kecuali pada perlakuan konsentrasi osmolit sorbitol terhadap rasio tajuk akar.

Berdasarkan Tabel 4.6 tersebut S0 menghasilkan berat kering total tertinggi yaitu $6,25 \mathrm{~g}$ yang menunjukkan berbeda nyata lebih tinggi dibandingkan dengan hasil berat kering S1, S2, dan S3. Pada W2 menunjukkan nilai berat kering yang paling rendah, yaitu 3,59 $\mathrm{g}$ dan menurunkan berat kering tanaman sebesar $95,82 \%$, berat kering pada W2 tidak berbeda nyata dengan W1. Pada W3 menurunkan berat kering tanaman yang paling rendah dibandingkan dengan $\mathrm{W} 1$ dan $\mathrm{W} 2$, yaitu $44,35 \%$. Sedangkan pada parameter pengamatan rasio tajuk akar intensitas cekaman kekeringan menunjukkan perlakuan pada W1, W2, W3 menunjukkan hasil yang tidak berbeda nyata.

\section{Indeks Panen}

Parameter indeks panen tidak menunjukkan pengaruh yang diakibatkan oleh interaksi dari pemberian konsentrasi osmolit sorbitol dan intensitas cekaman kekeringan, namun pada faktor pemberian konsentrasi osmolit sorbitol menunjukkan pengaruh nyata, sedangkan untuk faktor intensitas cekaman kekeringan menunjukkan tidak adanya pengaruh yang diberikan.

Berdasarkan Tabel 4.7 menunjukkan pemberian konsentrasi osmolit sorbitol S0, S1, dan S2 menunjukkan hasil yang tidak berbeda nyata, sedangkan S2 tidak berbeda nyata dengan S3 yang memiliki hasil indeks panen yang tertinggi yaitu 1,05 .

\section{Pembahasan}

Tanaman yang mengalami cekaman kekeringan akan menghasilkan pertumbuhan dan hasil produksi yang lebih rendah jika dibandingkan dengan tanaman pada kondisi air tercukupi (tanpa cekaman). Menurut Aminah (2013) hal ini terjadi karena jumlah air tidak mencukupi untuk aktivitas metabolisme, sehingga terjadi gangguan pada proses pertumbuhan dan perkembangan tanaman. Huang (2006) menjelaskan bahwa osmolit pada umumnya ditemukan pada tanaman, termasuk senyawa seperti gula, asam organik, polyols, nitrogen (seperti asam amino, amida, ectoine, protein, dan amonium quartener) dan beberapa ion anorganik seperti $\mathrm{K}^{+}, \mathrm{Ca}^{2+}, \mathrm{Na}^{+}$, dan $\mathrm{Cl}^{-}$. Senyawa-senyawa tersebut relatif berkontribusi untuk penyesuaian osmotik pada kondisi tercekam kekeringan. Hasil penelitian Guntoro (2008) pemberian sorbitol berpengaruh positif terhadap peningkatan kandungan air. Kandungan air relatif daun yang tinggi menyebabkan tekanan turgornya tinggi dan berakibat membukanya stomata. Tipe stomata juga mempengaruhi terjadinya proses transpirasi ataupun proses keluar masuknya gas ataupun air dari lingkungan ke dalam sel (Khoiroh et al., 2014). Tipe stomata dari tanaman kacang hijau adalah parasitic (gambar)( Siahpoos et al., 2015).

Tanaman dalam kondisi cekaman kekeringan tanpa pemberian osmolit sorbitol pada (S0) tinggi tanaman menujukkan nilai paling rendah (Tabel 4.1), yaitu $9,55 \mathrm{~cm}$ dan menunjukkan hasil yang berbeda nyata dengan perlakuan yang diberikan osmolit sorbitol dengan konsentrasi yang berbeda. Suhartono et al., (2008) memaparkan bahwa pemberian air dibawah kondisi optimum pada fase pertumbuhan tersebut akan menyebabkan kekerdilan pada tanaman. Cekaman kekeringan pada fase vegetatif lebih banyak berpengaruh terhadap pertumbuhan vegetatif dan kurang berpengaruh terhadap hasil (Pratiwi, 2011), sedangkan perlakuan pemberian osmolit sorbitol pada konsentrasi 10,20 , dan $30 \mathrm{ml} / \mathrm{l}$ pada stadia vegetatif menunjukkan hasil yang berbeda tidak nyata, hal ini berarti adanya penambahan osmolit sorbitol mampu meningkatkan daya adaptasi pada tinggi tanaman. lebar bukaan stomata pada perlakuan So lebih kecil jika dibandingkan dengan S1, S2, dan S3 pada kombinasi W1, sehingga diduga berlangsungnya fotosintesis tidak optimal. Tanaman kacang hijau termasuk dalam kelompok C3, menurut Taluta (2017) terutama pada tanaman $\mathrm{C} 3$ yang secara langsung menggunakan $\mathrm{CO}_{2}$ melalui siklus Calvin, derajat pembukaan dan penutupan stomata memiliki pengaruh penting pada aktivitas fotosintesis. Pada pengamatan ini seluruh perlakuan, kecuali cekaman kekeringan mulai stadia vegetatif (W1) juga menunjukkan berbeda tidak nyata, hal ini dikarenakan semua perlakuan tersebut belum mendapatkan perlakuan cekaman kekeringan, sehingga masih mendapatkan air yang cukup, sedangkan untuk 4-6 MST menunjukkan tidak adanya pengaruh terhadap perlakuan yang diberikan, hal ini diduga laju pertumbuhan tanaman kacang hijau berhenti, karena tanaman kacang hijau termasuk dalam kelompok tanaman indeterminate dan mulai 4 MST tanaman tersebut sudah menunjukkan adanya bunga yang muncul. Stadia vegetatif tersebut akan berakhir pada saat bunga mekar (Tickoo et al., dalam Iqbal et al., 2015). 


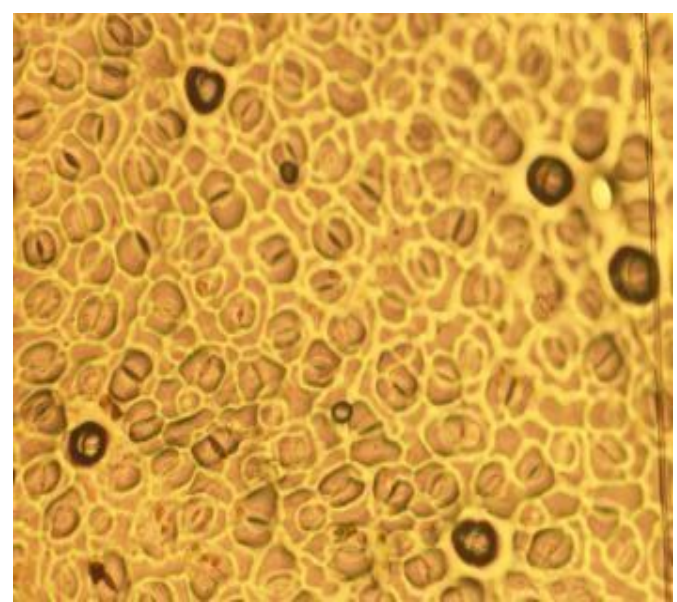

Gambar 4. 1. Contoh Stomata Kacang Hijau Berdasarkan hasil pengamatan stomata pada tanaman kacang hijau. (Gambar 4.2), pemberian konsentrasi osmolit sorbitol yang berbeda mempengaruhi bukaan stomata. Menurut Guntoro (2007) semakin tinggi pemberian konsentrasi osmolit sorbitol, maka bukaan stomata semakin lebar.

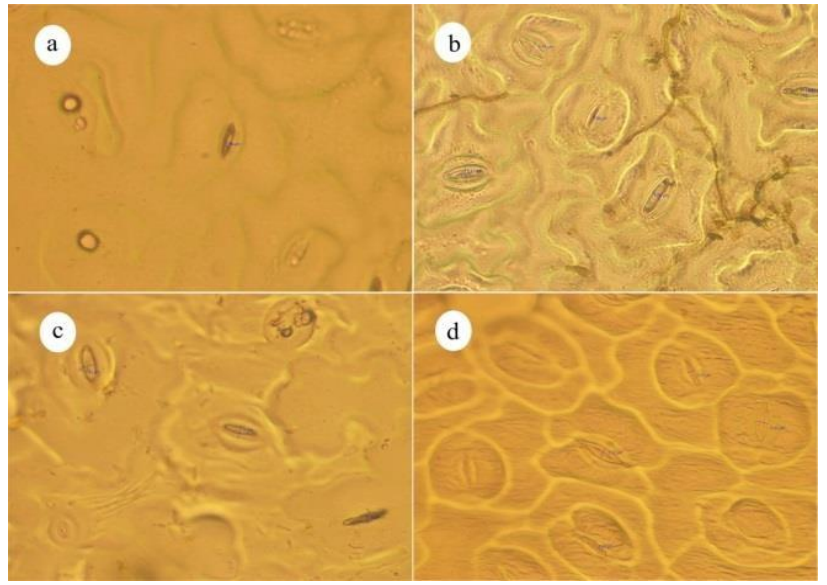

Gambar 4.2. Kondisi Stomata Akibat Penyemprotan Osmolit Sorbitol pada Konsentrasi yang Berbeda Keterangan: a) Konsentrasi 0 ml/l (S0); b) Konsentrasi 10 ml/l (S1), c) Konsentrasi 20 ml/l (S2); d) Konsentrasi 30 ml/l (S3)

Perlakuan tanpa pemberian osmolit (S0) menunjukkan cenderung nilai akar lebih panjang, hal ini berbanding lurus dengan berat kering tanaman yang ditunjukkan pada Tabel 4.6, menurut Gardner et al., (2008) pertumbuhan panjang dan lingkar akar umumnya beranalogi dengan pertumbuhan panjang dan lingkar pada pucuk. Akar tanaman yang lebih panjang memiliki kemampuan yang lebih baik dalam menyerap unsur hara dalam tanah dari pada akar yang lebih pendek (Dewi et al., 2014), sehingga pemberian osmolit sorbitol terhadap panjang akar tidak memberikan dampak. Cekaman kekeringan tidak menunjukkan pengaruh yang nyata, hal ini diduga karena ruang tumbuh akar terbatas oleh pot yang digunakan, sehingga pergerakan akar tanaman akan terbatas untuk penyerapan air. Menurut Sinaga (2008) penyebab menurunnya kemampuan akar yaitu terbatasnya pertumbuhan akar dan luas permukaan akar, dan juga menurunnya konduktivitas pembuluh pada akar.

Tabel 4.3 menunjukkan perlakuan S0W0 menunjukkan hasil terbaik, sedangkan pada W1 yang dikombinasikan dengan pemberian osmolit sorbitol S1 dan S2 tidak berbeda nyata dengan S0W1, hal ini berarti pemberian konsentrasi osmolit sorbitol tersebut tidak dapat meningkatkan jumlah polong utuh, jumlah total polong, dan berat kering polong, sedangkan pada kombinasi S3W1 dapat meningkatkan jumlah polong utuh sebesar $90 \%$, total polong $88,83 \%$ dan berat kering polong $94,22 \%$ pada kondisi tercekam mulai stadia vegetatif. Hal ini diduga pada konsentrasi pemberian osmolit sorbitol 10 dan 20 $\mathrm{ml} / \mathrm{l}$ kondisi bukaan stomata masih kurang untuk berfotosintesis sesuai yang diharapkan, hal ini selaras dengan penelitan. Guntoro (2007) dalam upaya meningkatkan adaptasi tanaman kedelai terhadap kondisi kekeringan sorbitol pada konsentrasi $10 \mathrm{ml} / \mathrm{l}$ belum mampu meningkatkan penimbunan kandungan sorbitol pada daun, sehingga ukuran membukanya stomata kecil, hal ini berakibat pada penyesuaian osmotik sel tidak terjadi, akibatnya kelembapan sel penjaga daun belum 
menghambat kerja ABA sehingga turgor sel penjaga daun rendah. Bukaan stomata pada S3W1 memiliki bukaan yang lebih besar dibandingkan S0W1, S1W1, dan S2W1 sehingga fotosintesis berlangsung lebih optimal. Kondisi kekeringan menyebabkan penurunan lebar stomata (Zhou et al., 2017). Menurut Sholihatun et al., (2016) penutupan stomata tersebut mempengaruhi pertukaran $\mathrm{CO}_{2}$ dan $\mathrm{O}_{2}$ yang selanjutnya mengakibatkan terganggunya metabolisme tanaman.

Pada W2 pemberian konsentrasi osmolit sorbitol tidak berbeda nyata terhadap jumlah polong utuh, jumlah total polong, dan berat kering polong pada semua konsentrasi yang diberikan. SOW2 cenderung memiliki nilai yang paling kecil dibandingkan dengan S1W2, S2W2, dan S2W3. Aminah (2013) memaparkan stadia vegetative dan stadia pembentukan bunga merupakan stadia pertumbuhan yang paling peka terhadap kondisi kekeringan. Kekeringan menginduksi awal berbunga meskipun demikian hal tersebut tidak ekonomis karena pengaturan polong yang buruk di bawah cekaman kekeringan (Ranawake, 2011). Lewar (2016) juga melaporkan jika cekaman kekeringan terjadi pada fase generatif akhir maka polong dan biji yang terbentuk mengecil ukurannya atau lebih sedikit jumlahnya dibandingkan dengan yang tumbuh dalam kondisi cukup air. Jumlah polong utuh pada tanaman yang mengalami cekaman kekeringan mulai stadia pengisian polong menunjukkan pada pemberian osmolit sorbitol 10 dan $20 \mathrm{ml} / \mathrm{l}$ tidak berbeda nyata dengan perlakuan tanpa pemberian osmolit sorbitol (S0). Pada kondisi tercekam kekeringan mulai stadia pengisian polong ini menunjukkan tidak berbeda nyata pada semua pemberian konsentrasi osmolit sorbitol pada jumlah total polong dan berat kering polong. Tanaman kacang hijau menggunakan air secara efesien dan biasanya tidak merespon pemberian air selama pengisian polong (Gentry, 2010), sehingga dari pernyataan tersebut diduga kebutuhan air pada stadia pengisian polong ini tidak sebanyak fase sebelumnya.

Parameter pengamatan jumlah biji (Tabel 4.4) berbanding lurus dengan berat biji per tanaman. Pada intensitas cekaman kekeringan mulai stadia vegetatif menujukkan pemberian osmolit sorbitol pada konsentrasi $10 \mathrm{ml} / \mathrm{l}$ menurunkan jumlah biji dan berat biji per tanaman sebesar $174 \%$ dan $201 \%$ pada kondisi cekaman kekeringan yang diberikan, sedangkan untuk konsentrasi osmolit sorbitol 20 dan $30 \mathrm{ml}$ tidak menunjukkan perbedaan yang nyata pada perlakuan intensitas cekaman kekeringan mulai stadia pembungaan dan pengisian polong. Hasil ini tidak berbanding lurus dengan berat kering polong per tanaman, hal ini dikarenakan hasil panen menunjukkan ukuran polong yang berbeda-beda sehingga mempengaruhi jumlah biji dan berat biji yang ada didalamnya (Gambar 4.3).

Cekaman kekeringan berpengaruh nyata pada berat 100 butir benih, namun semua perlakuan yang diberikan tidak berbeda nyata. W1 memilki nilai penurunan berat 100 butir yang paling tinggi yaitu $12,76 \%$. Hasil ini sejalan dengan hasil penelitian Lewar (2016) pada kondisi cekaman kekeringan $50 \%$ kapasitas lapangan. biji kacang hijau yang dihasilkan mempunyai ukuran biji yang lebih kecil dan ditemukan biji keriput.

Pemberian osmolit justru akan menurunkan hasil berat kering tanaman kacang hijau. Sorbitol merupakan salah satu osmolit yang mempunyai peranan sebagai pengendali kelembapan sel, sehingga turgor sel dapat dipertahankan (Aminah, 2013), dari pernyataan ini berarti pemberian osmolit pada masing- masing perlakuan kurang berfungsi karena turgor sel pada tanaman kacang hijau sudah cukup tinggi.

Cekaman kekeringan mulai stadia vegetatif dapat menurunkan berat kering tanaman sebesar 67,38\%, stadia pembungaan sebesar $100,37 \%$, dan stadia pengisian polong $44,25 \%$. Stadia pembungaan menurunkan berat kering tanaman lebih besar dari pada stadia yang lain. Hasil ini berbanding lurus dengan pendapat Arsyadmunir (2016) yaitu kekurangan air selama fase pembungaan hingga pembentukan polong akan mengakibatkan penurunan produksi. Mirzaei et al., (2014) juga melaporkan bahwa pengurangan jumlah irigasi secara tiba-tiba akan terjadi peningkatan suhu yang akan menyebabkan penuaan dini pada tanaman.

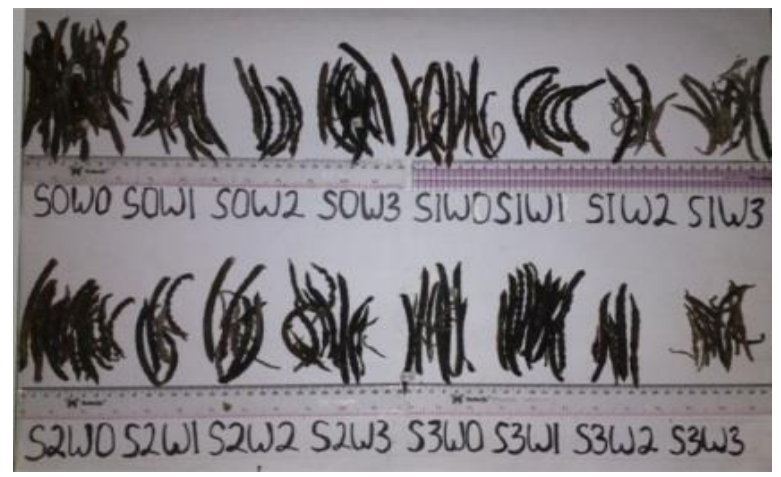

Gambar 4. 2. Polong Kering Hasil Panen 
Efendi dan Muhammad (2010) dalam penelitiannya berupa tanaman jagung pada kondisi cekaman kekeringan memicu tanaman untuk meningkatkan pertumbuhan akar dan menekan pertumbuhan tajuk sehingga rasio bobot kering akar/tajuk menjadi lebih besar yaitu 0,16-0,18 dibanding kondisi optimum hanya 0,14 . Terjadinya respons tersebut sebagai bentuk adaptasi tanaman terhadap kondisi cekaman kekeringan, terpacunya pertumbuhan akar akan memberi peluang yang lebih besar untuk mengabsorpsi air dengan menjangkau lapisan tanah yang lebih dalam, namun pada penelitian ini kurang selaras dengan panjang akar pada Tabel 4.2, pada hasil parameter panjang akar cekaman kekeringan tidak menunjukkan pengaruh terhadap panjang akar, sehingga panjang akar tidak selalu berbanding lurus dengan berat kering akar. Pada percobaan ini tanaman yang tercekam kekeringan memiliki rasio tajuk akar yang lebih kecil jika dibandingkam dengan tanaman yang mendapat pengairan normal, hal ini dikarenakan adanya akar yang pertumbuhanya tidak terlalu panjang namun banyak cabang akar yang muncul. Murti et al., (2006) dalam Muthahara et al., (2016) mengemukakan pemanjangan akar yang terhambat akan diteruskan dengan pertumbuhan sekunder yaitu pelebaran akar. Hal ini disebabkan oleh aktivitas meristem lateral yaitu pembentukan kambium. Pelebaran akar menyebabkan diameter akar semakin besar yang selanjutnya mempengaruhi bobot kering akar.

Pada tanaman kacang hijau produk yang dinilai ekonomis adalah biji, berdasarkan hasil percobaan terhadap parameter indeks panen menunjukkan tidak adanya pengaruh yang disebabkan interaksi antara faktor yang diberikan, namun pemberian konsentrasi osmolit sorbitol menunjukkan adanya pengaruh terhadap parameter tersebut. Tanaman yang disemprot dengan osmolit sorbitol 10 dan $20 \quad \mathrm{ml} / \mathrm{l}$ menunjukkan hasil yang tidak berbeda nyata dengan tanaman tanpa pemberian osmolit sorbitol (S0), namun pada konsentrasi $30 \mathrm{ml} / 1$ mampu meningkatkan indeks panen sebesar 41,89\%. Menurut Ariffin (2002) semakin tinggi nilai indeks panen berarti efesiensi tanaman dalam memanfaatkan produk fotosintat untuk pembentukan biji semakin tinggi.

\section{KESIMPULAN}

Berdasarkan hasil penelitian yang telah dilakukan dapat disimpulkan bahwa penyemprotan osmolit sorbitol dan intensitas cekaman kekeringan menunjukkan interaksi yang memberikan pengaruh terhadap beberapa parameter yang diamati, antara lain tinggi tanaman 3 MST, jumlah polong utuh, jumlah total polong, berat kering polong, jumlah biji, dan berat biji per tanaman, namun pemberian osmolit sorbitol 10, 20 , dan $30 \mathrm{~m} / \mathrm{l}$ belum mampu meningkatkan produksi kacang hijau pada kondisi tercekam kekeringan seperti pada kondisi normal.

\section{DAFTAR PUSTAKA}

Abdel, C. G., \& Al-Rawi, I. M. T. (2011). Response of mungbean (Vigna radiata L., Wilczek) to Gibberellic Acid (GA3) Rates and Varying Irrigation Frequencies. International Journal of Biosciences, 1(3), 85-92.

Al-Jebory, E. I. (2012). Effect of water stress on carbohydrate metabolism during Pisum sativum seedlings growth. Euphrates Journal of Agriculture Science, 4(4), 1-12.

Jusoff, K., Hadijah, S., Marliana, S. P., Muchtar, A. H., \& Nonci, M. (2013). Increasing soybean (Glycine max L) drought resistance with osmolit sorbitol. Modern Applied Science, 7(9), 78.

Ariffin. (2002). Cekaman Air dan Kehidupan Tanaman. $U B$ press. Malang.

Arsyadmunir, A. (2016). Periode kritis kekeringan pada pertumbuhan dan produksi kacang hijau (Vigna radiata L.). Agrovigor: Jurnal Agroekoteknologi,9(2), 132140.

Cahyadi, W. (2019). Analisis \& Aspek Kesehatan Bahan Tambahan Pangan.

Dewi, A. Y., Putra, E. T. S., \& Trisnowati, S. (2014). Induksi ketahanan kekeringan delapan hibrida kelapa sawit (Elaeis guineensis Jacq.) dengan silika. Vegetalika, 3(3), 1-13.

Directorate Plant Production. (2010). Mung Bean Production Guideline. Department Agriculture, Forestry and Fisheries Republic of South Africa.

Efendi, R., \& Azrai, M. (2010). Identifikasi karakter toleransi cekaman kekeringan berdasarkan respons pertumbuhan dan hasil genotipe jagung. Widyariset, 13(3), 41-50.

Fachruddin, I. L. (2000). Budi daya kacang kacangan. Kanisius.

Fathi, A., \& Tari, D. B. (2016). Effect of drought stress and its mechanism in plants. International Journal of Life Sciences, 10(1), 1-6.

Gardner, F. P., Pearce, R. B., \& Mitchell, R. L. (2008). Fisiologi Tanaman Budidaya (translate by Herawati Susilo). UI-Press. Jakarta.

Gentry, J. (2010). Mungbean Management Guide $2^{\text {nd }}$ Edision. Departement of Employment, Economic, Development and Innovation. Australia.

Hendriyani, I. S., \& Setiari, N. (2009). Kandungan klorofil dan 
pertumbuhan kacang panjang (Vigna sinensis) pada tingkat penyediaan air yang berbeda. Jurnal Sains \& Matematika, 17(3), 145-150.

H.F. Schwartz dan M.A.C. Langham. 2010. Growth Stages of Pea Pisum sativum L.(online),https://www.ndsu.edu/pubwe b/pulseinfo/growthstagespdf/peagrowth agescards.pdf, (diakses pada 14 November 2017).

Ichsan, C. N., Hayati, M., \& Mashtura, S. P. (2010). Respon kedelai kultivar kipas putih dan wilis pada kadar air tanah yang berbeda terhadap pertumbuhan dan hasil. Jurnal Agrista, 14(1), 29-29.

Iqbal, J., Ahsan, M., Saleem, M., \& Ali, A. (2015). Appraisal of gene action for indeterminate growth in mungbean [Vigna radiata (L.) Wilczek]. Frontiers in plant science, 6,665 .

Huang, B. (Ed.). (2016). Plant-environment interactions. CRC Press.

Hussain, F., Malik, A. U., Haji, M. A., \& Malghani, A. L. (2011). Growth and yield response of two cultivars of mungbean (Vigna radiata L.) to different potassium levels. J. Anim. Plant Sci, 21(3), 622-625.

Kalefetoğlu, T., \& Ekmekci, Y. (2005). The effects of drought on plants and tolerance mechanisms. Gazi University Journal of Science.

Kaur, R., Toor, A. K., Bassi, G., \& Bains, T. S. (2017). Characterization of Mungbean (Vigna radiata $\mathrm{L}$. Wilczek) varieties using morphological and molecular descriptors. Int. J. Curr. Microbiol. App. Sci, 6(6), 1609-1618.

Khoiroh, Y., Harijati, N., \& Mastuti, R. (2014). Pertumbuhan serta hubungan kerapatan stomata dan berat umbi pada Amorphophallus muelleri Blume dan Amorphophallus variabilis Blume. Biotropika: Journal of Tropical Biology, 2(5), 249-253.

Komalasari, W., B., Sri, W., Megawati, M., Sehusman, Rinawati, \& Yani, S. (2015). Buletin Konsumsi Pangan. Kementerian Pertanian. Jakarta (online) (http://epublikasi.setjen.pertanian.go.id/epublikasi/bul etin/konsumsi/2015/Buletin\%20Konsums\%20TW4\%2 02015/file s/assets/basic-html/page2.html, (diakses pada 8 Desember 2017).

Lakitan, B. (2004). Dasar-dasar Fisiologi Tumbuhan: Raja Grafindo Persada.
Lewar, Y. (2009). Efektivitas Kinetin Terhadap Kualitas Benih Kacang Hijau Fore Belu Yang Mengalami Cekaman Kekeringan Selama Fase Generatif. Partner, 16(2), 30-40.

Maleki, A., Naderi, A., Naseri, R., Fathi, A., Bahamin, S., \& Maleki, R. (2013). Physiological performance of soybean cultivars under drought stress. Bull. Env. Pharmacol. Life Sci, 2(6), 38-44.

Mirzaei, A., Naseri, R., Vafa, P., \& Moradi, M. (2014). Effects of drought stress on qualitative and quantitative traits of mungbean. International Journal of Agricultural and Biosystems Engineering, 8(2), 144-148.

Muthahara, E., Baskara, M., \& Herlina, N. (2018). Pengaruh Jenis Dan Volume Media Tanam Pada Pertumbuhan Tanaman Markisa (Passiflora Edulis Sims.). Jurnal Produksi Tanaman, 6(1).

Noiraud, N., Maurousset, L., \& Lemoine, R. (2001). Transport of polyols in higher plants. Plant Physiology and Biochemistry, 39(9), 717-728.

Rukundo, P., Carpentier, S., \& Swennen, R. (2012). Development of in vitro technique to screen for drought tolerant banana varieties by sorbitol induced osmotic stress. African Journal of Plant Science, 6(15), 416425 .

Pratiwi, H. (2013). Pengaruh kekeringan pada berbagai fase tumbuh kacang tanah. Buletin Palawija, (22), 71-78.

Purwono, \& Rudi. (2008). Kacang Hijau. Penebar Swadaya. Jakarta.

Martin, R. J., \& Jamieson, P. D. (1996). Effect of timing and intensity of drought on the growth and yield of field peas (Pisum sativum L.). New Zealand Journal of Crop and Horticultural Science, 24(2), 167-174.

Ranawake, A. L., Dahanayaka, N., Amarasingha, U. G. S., Rodrigo, W. D. R. J., \& Rodrigo, U. T. D. (2011). Effect of water stress on growth and yield of mung bean (Vigna radiata $\mathrm{L}$ ). Tropical agricultural research and extension, 14(4), 76-79.

Razavizadeh, R., \& Adabavazeh, F. (2017). Effects of sorbitol on essential oil of Carum copticum L. under in vitro culture. Rom Biotechnol Lett, 22(1), 12281-12289.

Schwartz, H. F., Brick, M. A., Harveson, R. M., \& Franc, G. D. (2004). Dry bean production \& integrated pest management. Regional publication by Central High Plains Dry Bean and Beet Group, Colorado State 
University, University of Nebraska, and University of Wyoming: Bulletin, 5, 62.

Shinozaki, K., \& Yamaguchi-Shinozaki, K. (2007). Gene networks involved in drought stress response and tolerance. Journal of experimental botany, 58(2), 221227.

Sholihatun, F., Putra, E. T. S., \& Kastono, D. (2014). Induksi ketahanan kekeringan delapan hibrida kelapa sawit (Elaeis guineensis Jacq.) dengan boron. Vegetalika, 3(3), 14-26.

Siahpoosh, A., Ghasemi, M., Majd, A., \& Rajabi, H. (2015). Vegetative and reproductive anatomy of Vigna radiata L. An International Journal Society for Tropical Plant Research.

Sinaga, R. (2008). Keterkaitan nisbah tajuk akar dan efisiensi penggunaan air pada rumput gajah dan rumput raja akibat penurunan ketersediaan air tanah.

Soesilo, D., Santoso, R. E., \& Diyatri, I. (2005). Peranan sorbitol dalam mempertahankan kestabilan $\mathrm{pH}$ saliva pada proses pencegahan karies (The role of sorbitol in maintaining saliva's $\mathrm{pH}$ to prevent caries process). Dental Journal (Majalah Kedokteran Gigi), 38(1), 25-28.

Solichatun, E. A., \& Mudyantini, W. (2005). Pengaruh ketersediaan air terhadap pertumbuhan dan kandungan bahan aktif saponin tanaman ginseng jawa (Talinum paniculatum Gaertn.). Biofarmasi, 3(2), 47-51.

Subantoro, R. (2014). Pengaruh Cekaman Kekeringan terhadap Respon Fisiologis Perkecambahan Benih Kacang Tanah (Arachis hypogaea L). Mediagro, 10(2).
Suhartono, R.A Zidqi, Z., Z., M, \& Khoiruddin, A. (2008). Pengaruh interval pemberian air terhadap pertumbuhan dan hasil tanaman kedelai (gilicine $\max (1)$ merril) pada berbagai jenis tanah. Embryo, 5(1), 98-112.

Taluta, H. E., Rampe, H. L., \& Rumondor, M. J. (2017). Pengukuran panjang dan lebar pori stomata daun beberapa varietas tanaman kacang tanah (Arachis hypogaea L.). Jurnal MIPA, 6(2), 1-5.

Tribun Timur. (2017). 7 Potret Kekeringan Berbagai Daerah di Indonesia (online), http://makassar.tribunnews.com/2017/0 9/19/7-potretkekeringan-berbagai daerah-di-indonesia-tahun-ini-no2- dan-6-menyedihkan, (diakses pada 23 Oktober 2017).

Trustinah, T., Radjit, B. S., Prasetiaswati, N., \& Harnowo, D. (2015). Adopsi varietas unggul kacang hijau di sentra produksi. Iptek Tanaman Pangan, 9(1).

Yasmeen, T., Hameed, S., Tariq, M., \& Iqbal, J. (2012). Vigna radiata root associated mycorrhizae and their helping bacteria for improving crop productivity. Pak. J. Bot, 44(1), 87-94.

Zare, M., Dehghani, B., Alizadeh, O., \& Azarpanah, A. (2013). The evaluation of various agronomic traits of mungbean (Vigna radiate L.) genotypes under drought stress and non-stress conditions. International Journal of Farming and Allied Sciences, 2(19), 764-770.

Zhou, R., Yu, X., Ottosen, C. O., Rosenqvist, E., Zhao, L., Wang, Y., ... \& Wu, Z. (2017). Drought stress had a predominant effect over heat stress on three tomato cultivars subjected to combined stress. BMC plant biology, 17(1), 1-13. 